\title{
CFL light promoted one-pot synthesis of pyrano[3,2-c]chromen-5(4H)-ones
}

\section{Ankusab Noorahmadsab Nadaf \& Kalegowda Shivashankar}

To cite this article: Ankusab Noorahmadsab Nadaf \& Kalegowda Shivashankar (2018) CFL light promoted one-pot synthesis of pyrano[3,2-c]chromen-5(4H)-ones, Synthetic Communications, 48:7, 809-815, DOI: 10.1080/00397911.2018.1426101

To link to this article: https://doi.org/10.1080/00397911.2018.1426101

View supplementary material ๔

曲 Published online: 27 Feb 2018.

Submit your article to this journal ๘

Џ Article views: 255

View Crossmark data ¿

Citing articles: 2 View citing articles $\square$ 


\title{
CFL light promoted one-pot synthesis of pyrano[3,2-c] chromen-5(4H)-ones
}

\author{
Ankusab Noorahmadsab Nadaf and Kalegowda Shivashankar \\ P. G. Department of Chemistry, Bangalore University, Bangalore, Karnataka, India
}

\begin{abstract}
An eco-friendly synthesis of pyrano[3,2-c]chromen-5(4H)-one derivatives was conducted by the condensation of 4-hydroxycoumarins, aromatic aldehydes, and acetophenones. Clean profile, excellent yield, ambient temperature, and use of visible light intensity instead of catalyst are the attractive features of this method.
\end{abstract}

\section{GRAPHICAL ABSTRACT}

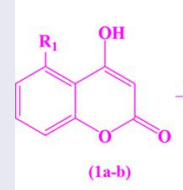
(1a-b)

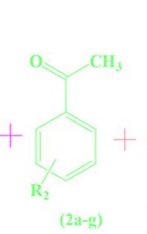
RT, Ethanol, Stirr for 3-3.5 hour

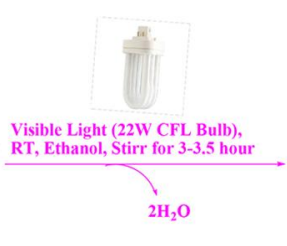

$2 \mathrm{H}_{2} \mathrm{O}$

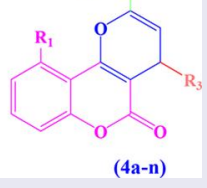

\section{ARTICLE HISTORY}

Received 6 November 2017

\section{KEYWORDS}

CFL light; coumarins;

photoorganic;

pyranocoumarins; pyrans;

visible light

\section{Introduction}

Unique chemical, ${ }^{[1]}$ biological, ${ }^{[2]}$ and physical properties ${ }^{[3]}$ associated with pyran derivatives have found broad applications as agrochemical and drugs. Pyran derivatives are widespread in nature. They are core skeletons in numerous natural products such as Frutinone A and Frutinone C (Polygala fruticosa) and Isoethulia-coumarin C (Ethulia conyzoides) ${ }^{[4]}$ (Fig. 1). The presence of pyran architectures in nature with antimicrobial, ${ }^{[5]}$ anticancer, ${ }^{[6]}$ antidyslipidemic, ${ }^{[7]}$ antihyperglycemic, ${ }^{[8]}$ anti-HIV,${ }^{[9]}$ antioxidant, ${ }^{[10]}$ antiallergic, ${ }^{[1]}{ }^{\text {xan- }}$ thine oxidase inhibitory, ${ }^{[12]}$ acetylcholinesterase, and butyrylcholinesterase inhibitory, ${ }^{[13]}$ Src kinase inhibitory activities ${ }^{[14]}$ made it a privileged structure.

Extensive research efforts have been focused on development of various strategies${ }^{[15,16]}$ for the synthesizing pyran derivatives. Few general methods are (i) one-pot condensation of aromatic aldehydes, malanonitrile/ethylcyanoacetate, and a-hydroxy $\mathrm{C}-\mathrm{H}$ acids $^{[17]}$ (ii) four-component reactions of arylamine, acetylenedicarboxylate, aromatic aldehydes, and cyclic 1,3-diketones ${ }^{[18]}$ (iii) intramolecular alkoxycarbonylative annulation $^{[19]}$ (iv) one-pot synthesis of pyran-based heterocycles from benzyl halides as key reagents. ${ }^{[20]}$ Even though synthesis of pyran derivatives using variety of catalysts such as $\mathrm{ZnFe}_{2} \mathrm{O}_{4}$, ${ }^{[21]}$ cellulose-perchloric acid, ${ }^{[22]}$ meglumine, ${ }^{[23]}$ gold(III), ${ }^{[24]}$ nickel 
<smiles>O=c1oc2ccccc2c2c1Cc1ccccc1O2</smiles>

Frutinone A (Polygala fruticosa)<smiles>O=c1oc2ccccc2c2c1Oc1c(O)cccc1C2</smiles>

Frutinone C (Polygala fruticosa)<smiles>C=C[C@]1(C)C=C(C(O)C(C)(C)O)Oc2c1c(=O)oc1cccc(C)c21</smiles>

Isoethulia-coumarin $\mathbf{C}$

(Ethulia conyzoides)

Figure 1. A few natural products embedded with pyranocoumarin core skeleton.

nanoparticles, ${ }^{[25]} \mathrm{DBU},{ }^{[26]} \mathrm{Fe}\left(\mathrm{HSO}_{4}\right)_{3},{ }^{[27]} \mathrm{Ce}\left(\mathrm{SO}_{4}\right)_{2} \cdot 4 \mathrm{H}_{2} \mathrm{O},{ }^{[28]}$ and ionic liquid ${ }^{[29]}$ have made tremendous progress in the past years, this reaction still has limitations including nongeneralization, use of excess amount of expensive catalysts, harsh reaction condition, low yields, and long reaction time. Therefore, an ideal protocol would install the desired pyran scaffolds in a time-efficient and one-pot procedure.

\section{Results and discussion}

Initially, 4-hydroxycoumarin (1a), 4-bromoacetophenone (2b), and 4-nitrobenzaldehyde (3f) were selected as model substrates for the reaction discovery and optimization (Scheme 1). When the model reaction was conducted under the visible light intensity (CFL, $20 \mathrm{~W}$ ) in DMF at room temperature for $4 \mathrm{~h}$, the pyrano[3,2-c]chromen-5(4H)one (4f) was obtained in $50 \%$ yield. In the absence of visible light intensity, no reaction was observed.

The effect of solvent on the reaction was examined and ethanol is the best choice. When the model reaction was conducted in ethanol, 94\% yield of (4f) was generated (Table 1). Other solvents such as dioxane, THF, DMF, DMSO, acetonitrile, methanol, toluene, and dichloromethane showed less reactivity providing (4f) in $42-78 \%$ yields. On varying the visible light intensity from 8 to $32 \mathrm{~W}$, the best yield of (4f) was obtained in $22 \mathrm{~W}$ at room temperature.

With the optimal condition for the synthesis of pyranocoumarins on hand, we studied the scope of this multicomponent process (Table 2). Various aromatic aldehydes and acetophenones containing electron-donating and electron-withdrawing substituents at ortho,
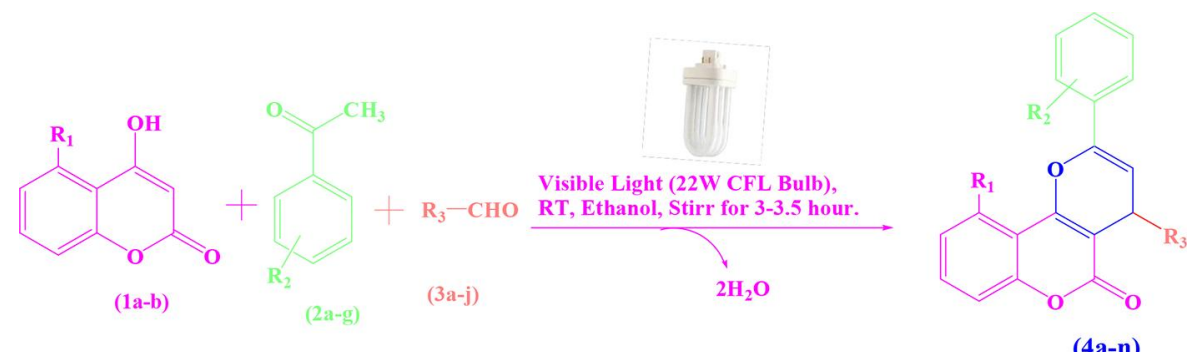

Scheme 1. Synthesis of pyranocoumarin derivatives under visible light condition at ambient temperature. 
Table 1. Optimization of visible light intensity and solvent screen for the synthesis of (4f).

\begin{tabular}{rcccc}
\hline Entry & Solvent & Visible light intensity $(\mathrm{W})$ & Time $(\mathrm{h})$ & Yield (\%) \\
\hline 1 & Dioxane & 20 & 5.5 & 78 \\
2 & THF & 20 & 5 & 62 \\
3 & DMF & 20 & 4.0 & 50 \\
4 & DMSO & 20 & 5.5 & 42 \\
5 & Acetonitrile & 20 & 4 & 68 \\
6 & Methanol & 20 & 3.5 & 72 \\
7 & Toluene & 20 & 4.5 & 60 \\
8 & $\mathrm{CH}_{2} \mathrm{Cl}_{2}$ & 20 & 4.0 & 48 \\
9 & Ethanol & 20 & 2.3 & 78 \\
10 & Ethanol & 22 & 3 & 94 \\
11 & Ethanol & 15 & 3.5 & 77 \\
12 & Ethanol & 8 & 4.2 & 43 \\
13 & Ethanol & 32 & 3 & 89 \\
\hline
\end{tabular}

Bold values represents the best results.

Table 2. Synthesis of pyranocoumarin derivatives under visible light condition.

\begin{tabular}{|c|c|c|c|c|c|c|}
\hline No. & $R_{1}$ & $\mathrm{R}_{2}$ & $\mathrm{R}_{3}$ & Product & Time (h) & Yield (\%) \\
\hline 1 & $\mathrm{H}$ & $\mathrm{H}$ & & $4 a$ & 3.0 & 89 \\
\hline 2 & $\mathrm{H}$ & $4-\mathrm{Br}$ & & $4 b$ & 3.4 & 88 \\
\hline 3 & $\mathrm{H}$ & $4-B r$ & & $4 c$ & 3.3 & 87 \\
\hline 4 & $\mathrm{H}$ & $4-\mathrm{Br}$ & & $4 d$ & 3.5 & 90 \\
\hline 5 & $\mathrm{H}$ & $4-B r$ & & $4 e$ & 3.3 & 92 \\
\hline 6 & $\mathrm{H}$ & $4-\mathrm{Br}$ & & $4 f$ & 3.0 & 94 \\
\hline 7 & $\mathrm{H}$ & $4-B r$ & $H$ & $4 \mathrm{~g}$ & 3.2 & 96 \\
\hline 8 & $\mathrm{H}$ & $3-\mathrm{CH}_{3}, 4-\mathrm{OH}$ & 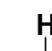 & 4h & 3.5 & 92 \\
\hline 9 & $\mathrm{H}$ & $2-\mathrm{Cl}, 4-\mathrm{Cl}$ & 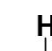 & $4 i$ & 3.4 & 96 \\
\hline
\end{tabular}


Table 2. Continued.

\begin{tabular}{|c|c|c|c|c|c|c|}
\hline No. & $R_{1}$ & $\mathrm{R}_{2}$ & $\mathrm{R}_{3}$ & Product & Time (h) & Yield (\%) \\
\hline 10 & $\mathrm{H}$ & $4-\mathrm{NO}_{2}$ & & $4 j$ & 3.2 & 90 \\
\hline 11 & $\mathrm{H}$ & $2-\mathrm{NO}_{2}$ & & $4 k$ & 3.3 & 90 \\
\hline 12 & $\mathrm{Cl}$ & $3-\mathrm{NO}_{2}$ & & 41 & 3.2 & 91 \\
\hline 13 & $\mathrm{Cl}$ & $3-\mathrm{NO}_{2}$ & & $4 m$ & 3.0 & 89 \\
\hline 14 & $\mathrm{Cl}$ & $2-\mathrm{Cl}, 4-\mathrm{Cl}$ & & $4 n$ & 3.2 & 91 \\
\hline
\end{tabular}

meta, and para positions exhibited equal ease towards the product formation in excellent yields ranging from 87 to $96 \%$. Heteroaromatic aldehydes such as imidazole and indole could also be accepted in the reaction. 5-Chloro-4-hydroxycoumarin was applied in the reaction instead of 4-hydroxycoumarin that successfully led to the corresponding pyrano $[3,2-c]$ chromen-5(4H)-ones in high yields.

On the basis of the above mentioned experimental results, a plausible reaction mechanism (Scheme 2) is proposed for the formation of pyranocoumarin derivatives. ${ }^{[30-34]}$ Aldehydes (3a-j) undergo condensation with acetophenones (2a-i) to afford a chalcones. Michael addition of 4-hydroxycoumarins (1a-b) with chalcones produces the intermediate that on intramolecular cyclization gives the pyranocoumarins $(\mathbf{4 a}-\mathbf{n})$.

To know, whether the reaction takes place in a radical pathway or ionic pathway, the same model reaction was performed in the presence of hydroquinone which is a radical inhibitor. ${ }^{[35]}$ The result indicated that only a trace amount of (4f) was produced. This experiment clearly demonstrated that the reaction proceeds in a radical pathway.

\section{Conclusion}

In conclusion, we have developed a one-pot methodology for the efficient synthesis of pyranocoumarin derivatives under visible light condition. Excellent yields, easy workup, ambient temperature, and short reaction time are the key advantages of this protocol.

\section{General information}

The melting points were determined using electric melting point apparatus with a calibrated thermometer. $\mathrm{H}^{1}$-NMR spectra were recorded using a Bruker/Jeol spectrophotometer operating at $400 \mathrm{MHz}$ and $\mathrm{C}^{13}$-NMR spectra were recorded at $100 \mathrm{MHz}$. The spectra were measured in $\mathrm{CDCl}_{3} / \mathrm{DMSO}-d_{6}$ relative to tetramethylsilane (TMS) (0.00 ppm). HRMS spectra were recorded using Waters Model: Synapt G2. The elemental 


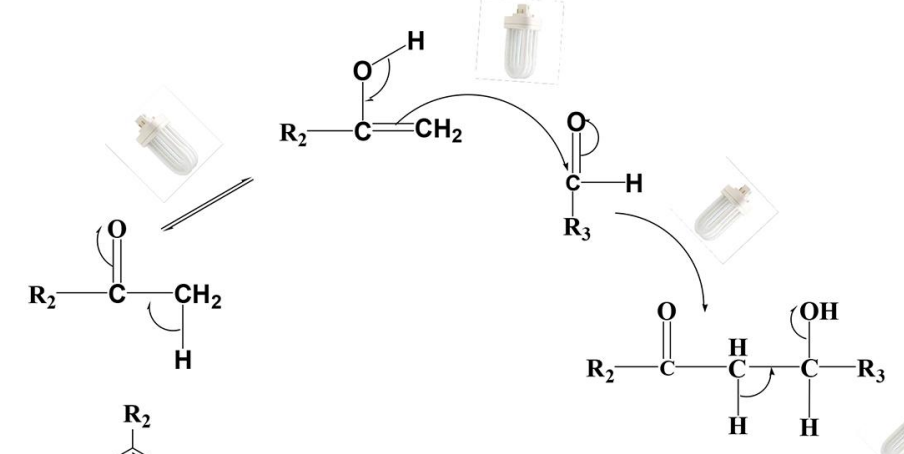

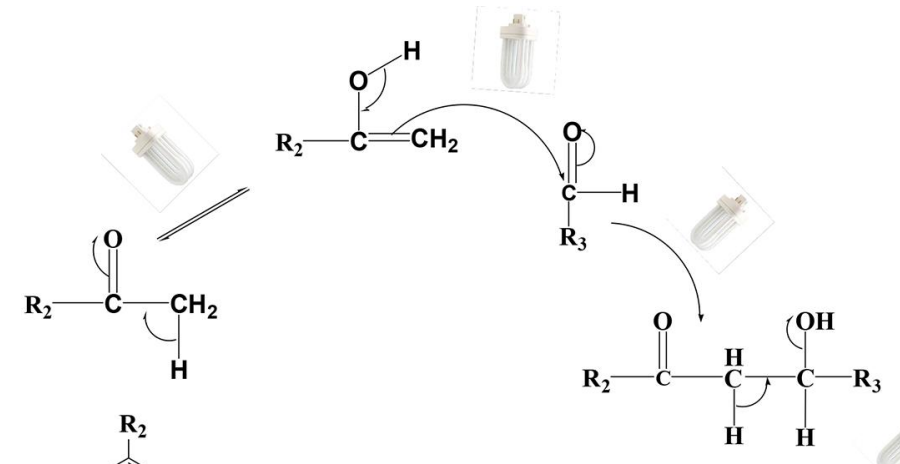<smiles>[R1]C1=CC([R3])c2c(c3c([R])cccc3oc2=O)O1</smiles><smiles>[R]c1cc2ccc1OC(=O)C([R3])C([R1])CC([R1])(Cl)CCC2=O</smiles><smiles>CC(C)C=O</smiles>

Scheme 2. Proposed radical pathway for the formation of pyranocoumarin derivatives under visible light condition.

analyses were determined on Elemental Vario Micro Cube CHN Rapid Analyzer. CFL bulbs manufactured by Philips company were used for reaction conditions.

Typical procedure for the synthesis of 2-(phenyl)-4-(phenyl)pyrano[3,2-c] chromen-5(4H)-one (4a)

A $100 \mathrm{ml}$ beaker was charged with 4-hydroxycoumarin (1a) $(1 \mathrm{mmol})$, acetophenone (2a) $(1 \mathrm{mmol})$ and benzaldehyde (3a) $(1 \mathrm{mmol})$ in ethanol $(10 \mathrm{~mL})$. A glowing CFL bulb $(22 \mathrm{~W})$ was put inside the beaker but above the surface of the reaction mixture that was stirred under ambient condition for $3 \mathrm{~h}$. The reaction progress and completion were monitored by TLC (Eluent: EtoAc and $n$-hexane). The organic layer was concentrated under reduce pressure. The residue was purified by recrystallization.

\section{2-(Phenyl)-4-(phenyl)pyrano[3,2-c]chromen-5(4H)-one (4a)}

A white solid, $313.3778 \mathrm{mg}$ (89\% yield). Mp 176-178 ${ }^{\circ} \mathrm{C} .{ }^{1} \mathrm{H}$ NMR (DMSO- $\left.d_{6} 400 \mathrm{MHz}\right): \delta$ $6.30(\mathrm{~s}, 1 \mathrm{H}, \mathrm{CH}) 7.07-7.84\left(\mathrm{~m}, 15 \mathrm{H}, 14 \mathrm{Ar}-\mathrm{H} \& 1\right.$ Pyran-H) ppm. ${ }^{13} \mathrm{C} \mathrm{NMR}\left(\mathrm{CDCl}_{3} 100 \mathrm{MHz}\right)$ : $\delta 62.1,110.7,111.0,116.7,122.3,123.3,123.5,124.1,124.5,125.1,129.0,129.2,129.5,130.1$, 132.6, 138.2, 144.0, 144.2, 144.5, 144.7, 155.7, 155.9 (2C), 168.9 ppm. HRMS: $[\mathrm{M}]=m / z$ 353.1645; Anal. Calcd for $\mathrm{C}_{24} \mathrm{H}_{16} \mathrm{O}_{3}$ : C, 81.80; H, 4.58; found: C, 81.60; H, 4.55\%. 


\section{Associated content}

\section{Supporting information}

${ }^{1} \mathrm{H}$ NMR, ${ }^{13} \mathrm{C}$ NMR, HRMS spectra, elemental analyses data, and experimental details for the compounds (4b-n).

\section{Funding}

This work is generously supported by the Department of Science and Technology-Science and Engineering Research Board (DST-SERB), New Delhi, India under the Fast Track Young Scientist Scheme (Grant No: SB/FT/CS-028/2013 dated: 09.06.2014, 24.09.2015, and 12.09.2016) in the form of major research project.

\section{References}

[1] Vekariya, R. H.; Patel, H. D. Synth. Commun. 2014, 44, 2756.

[2] Dar, A. M.; Shamsuzzaman. Eur. Chem. Bull. 2015, 4, 249.

[3] Kaur, C.; Dhiman, S.; Singh, H.; Kaur, M.; Bhagat, S.; Gupta, M.; Sharma, S.; Bedi, P. M. S. Asian J. Biochem. Pharm. Res. 2015, 7, 127.

[4] Murray, R. D. H. Fortchemie 1991, 35, 1.

[5] Makawana, J. A.; Patel, M. P.; Patel, R. G. Arch. Pharm. Chem. Life Sci. 2012, 345, 314.

[6] Emmadi, N. R.; Atmakur, K.; Chityal, G. K.; Pombala, S. J.; Nanubolu, B. Bioorg. Med. Chem. Lett. 2012, 22, 7261.

[7] Kumar, A.; Maurya, R. A.; Sharma, S. A.; Ahmad, P.; Singh, A. B.; Bhatia, G.; Srivastava, A. K. Bioorg. Med. Chem. Lett. 2009, 19, 6447.

[8] Wang, H.; Lu, J.; Zhang, Z. Monatsh Chem. 2010, 141, 1107.

[9] Mansoor, S. S.; Logaiya, K.; Aswin, K.; Sudhan, P. N. J. Taibah Univ. Sci. 2015, 9, 213.

[10] Symeonidis, T.; Chamilos, M.; Litina, D. J. H.; Kallitsakis, M.; Litinas, K. E. Bioorg. Med. Chem. Lett. 2009, 19, 1139.

[11] Coudert, P.; Couquelet, J. M.; Bastide, J.; Marion, Y.; Fialip, J. Ann. Pharm. Fr. 1988, 46, 91.

[12] Kaur, R.; Naaz, F.; Bedi, P. M. S.; Sharma, S.; Nepali, K.; Mehndiratta, S.; Gupta, M. K. Med. Chem. Res. 2015, 24, 3334.

[13] Khoobi, M.; Alipour, M.; Sakhteman, A.; Nadri, H.; Moradi, A.; Emami, S.; Foroumadi, A.; Shafiee, A. Eur. J. Med. Chem. 2013, 68, 260.

[14] Rafinejad, A.; Fallah-Tafti, A.; Tiwari, R.; Shirazi, A. N.; Mandal, D.; Shafiee, A.; Parang, K.; Foroumadi, A.; Akbarzadeh, T. DARU J. Pharm. Sci. 2012, 20, 1.

[15] Gu, Y.; Jerome, F. Chem. Soc. Rev. 2013, 42, 9550.

[16] Virdi, H. S.; Sharma, S.; Mehndiratta, S; Bedi, P. M. S.; Nepali, K. J. Enzyme Inhib. Med. Chem. 2015, 30, 730 .

[17] Shaterian, H. R.; Honarmand, M. Synth. Commun. 2011, 41, 3573.

[18] Sun, J.; Xia, E. Y.; Wu, Q.; Yan, C. G. ACS Comb. Sci. 2011, 13, 421.

[19] Li, Z.; Gao, Y.; Jiao, Z.; Wu, N.; Wang, D. Z.; Yang, Z. Org. Lett. 2008, 10, 5163.

[20] Beerappa, M.; Shivashankar, K. RSC Adv. 2015, 5, 30364.

[21] Das, P.; Dutta, A.; Bhaumikb, A.; Mukhopadhyay, C. Green Chem. 2014, 16, 1426.

[22] Khan, T.; Siddiqui, Z. N. New J. Chem. 2014, 38, 4847.

[23] Guo, R. Y.; An, Z. M.; Mo, L. P.; Wang, R. Z.; Liu, H. X.; Wang, S. X.; Zhang, Z. H. ACS Comb. Sci. 2013, 15, 557.

[24] Liu, Y.; Zhu, J.; Qian, J.; Jiang, B.; Xu, Z. J. Org. Chem. 2011, 76, 9096.

[25] Khurana, J. M.; Vij, K. Synth. Commun. 2013, 14, 2294.

[26] Saluja, P.; Aggarwal, K.; Khurana, J. M. Synth. Commun. 2013, 43, 3239.

[27] Eshghi, H.; Damavandi, S.; Zohuri, G. H. Synth. React. Inorg. Met.-Org. Chem. 2011, $41,1067$. 
[28] Islami, M. R.; Mosaddegh, E. Phosphorus Sulfur Silicon 2009, 184, 3134.

[29] Wen, L. R.; Xie, H. Y.; Li, M. J. Heterocycl. Chem. 2009, 46, 954.

[30] Haas, Y. Photochem. Photobiol. Sci. 2004, 3, 6.

[31] Hoffmann, N. Chem. Rev. 2008, 108, 1052.

[32] Tiwari, J.; Saquib, M.; Singh, S.; Tufail, F.; Singh, M.; Singh, J.; Singh, J. Green Chem. 2016, 18, 3221.

[33] Hari, D. P.; Konig, B. Org. Lett. 2011, 13, 3852.

[34] Yadav, S.; Srivastava, M.; Rai, P.; Singh, J.; Tiwari, K. P.; Singh, J. New J. Chem. 2015, 39, 4556.

[35] Zhang, M.; Fu, Q. Y.; Gao, G.; He, H. Y.; Zhang, Y.; Wu, Y. S.; Zhang, Z. H. ACS Sustainable Chem. Eng. 2017, 5, 6175. 